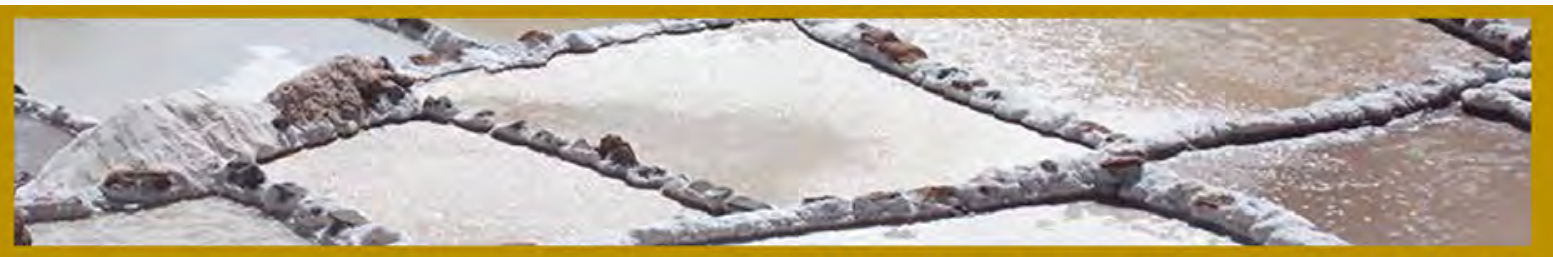

\title{
O FORTALECIMENTO DO CONSELHO ESCOLAR NO CENTRO EDUCACIONAL MUNICIPAL SÃO CRISTÓVÃO: REFLEXÕES E MUDANÇAS
}

\author{
STRENGTHEN SCHOOL COUNCIL IN SÃO CRISTOVÃO \\ MUNICIPAL EDUCATIONAL CENTER: REFLECTIONS AND \\ CHANGES
}

DOI: http://dx.doi.org/10.5965/1984317814012018036

Tiago Borga e Arã Paraguassu - Ribeiro Universidade do Alto Vale do Rio do Peixe Mariangela Lenz Zeide - Universidade Federal do Rio Grande do Sul Rodrigo Regert - Universidade Alto Vale do Rio do Peixe

\begin{abstract}
Resumo: Este estudo apresenta uma reflexão sobre o fortalecimento do Conselho Escolar no Centro Educacional Municipal São Cristóvão de Fraiburgo SC, como um recorte do Projeto de Intervenção proposto no curso. O projeto foi criado com o intuito de discutir a importância, a função de cada membro e as ações que esse Conselho deve executar para que exerça papel significativo na comunidade. Descrevemos as ações desenvolvidas para a efetiva implantação do Conselho Escolar, a partir de palestras, discussões com a comunidade e da distribuição de livros e cartilhas. Concluímos que a criação do Conselho contribuiu para obtermos, no Centro Educacional, uma educação democrática e de qualidade, a partir da qual alunos e comunidade interagem para a construção de uma escola cidadã.
\end{abstract}

Palavras-chave: Conselho Escolar; Gestão Escolar Democrática; Órgão Participativo.

\begin{abstract}
This study presents a reflection on strengthening the School Board in the São Cristovão Municipal Educational Center of Fraiburgo SC, as a important view in the course of the proposed Intervention Project. The project was created in order to discuss the importance, the role of each member and the actions that this Council must perform to exert significant role in the community. We describe the actions taken for the effective implementation of the School Board, from lectures, discussions with the community and distribution of books and booklets. We conclude that the creation of the Council contributed to obtain, at the Educational Center, a democratic and quality education, from which students and the community interact to building a citizen school.
\end{abstract}

Keywords: School Board; Democratic School Management; Participatory Organization.

\section{INTRODUÇÃ̃o}

O Conselho Escolar é um órgão participativo da gestão escolar que tem o dever de zelar por uma educação de qualidade. Para tanto, deve ser entendido como um órgão coletivo 


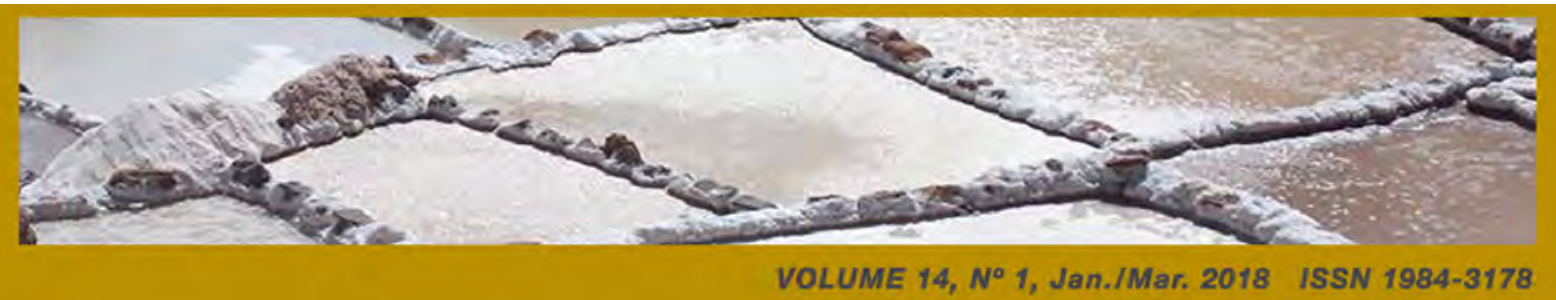

de decisões colegiadas, sendo um espaço de reflexão e estudo. Tem como finalidade acompanhar a gestão e o trabalho educativo escolar, no sentido da busca de alternativas para o enfrentamento de problemas e dificuldades, e implantar e implementar inovações.

É importante que tenhamos clareza de que democracia é algo que se aprende principalmente a praticando e vivenciando. No caso da democratização da gestão, esta é amparada na melhoria na qualidade pedagógica educacional das escolas e na construção de um currículo ajustado à realidade em que a escola está inserida. Também está pautada na integração efetiva dos envolvidos no processo educativo de modo direto ou indireto, sendo estes o diretor, os professores, os estudantes, os coordenadores, os administradores, os vigias e auxiliares, com o apoio constante da comunidade como participante ativa do processo de desenvolvimento do trabalho escolar. A escola, portanto, como espaço social da educação de qualidade e também de inclusão social, é um espaço privilegiado de formação humana.

Este estudo tem como objetivo principal analisar no contexto escolar a função do Conselho Escolar, diferenciando-o da Associação de Pais e Professores (APP). Como objetivos específicos, elencamos: conhecer a função do Conselho Escolar; identificar a forma legal para a consolidação do Conselho Escolar; analisar a diferença entre a APP e o Conselho Escolar para a comunidade escolar. O tema da pesquisa se originou da implantação do Conselho Escolar no Centro Educacional São Cristóvão, a partir de uma reflexão sobre as observações feitas durante a implantação do projeto de intervenção e das pesquisas bibliográficas.

$O$ projeto de intervenção ${ }^{1}$ foi desenvolvido em grupo e teve como título "O Fortalecimento do Conselho Escolar no Centro Educacional Municipal São Cristóvão". O Centro Educacional São Cristóvão, localizado no município de Fraiburgo/SC, vinculado à rede municipal de ensino, conta com aproximadamente 170 alunos na faixa etária de cinco a onze anos, atendendo à Educação Infantil e ao Ensino Fundamental, e ainda com quinze professores, quatro funcionários e um diretor.

Como, no município, foi imposta a obrigatoriedade da implantação do Conselho Escolar, houve a necessidade de se conhecerem as atribuições desse conselho e se discutirem

\footnotetext{
${ }^{1}$ O Projeto de Intervenção foi desenvolvido como requisito do curso de Especialização em Gestão Escolar e desenvolvido pelo grupo Arã Paraguassu Ribeiro, Denílson Dalagnol, Marinez Gueller e Marli Faquin.
} 
com a comunidade as suas atribuições. A Secretaria de Educação também determinou que as escolas extinguissem as APPs e criassem os conselhos escolares.

Diante dessa situação, percebe-se a necessidade de se desenvolverem ações que evidenciem a importância do Conselho Escolar na escola e para a comunidade escolar, no sentido de que esse Conselho possa exercer papel significativo na educação.

\section{GESTÃO DEMOCRÁTICA, PROJETO POLÍTICO-PEDAGÓGICO E CONSELHO ESCOLAR}

Na legislação brasileira, no artigo 3. ${ }^{\circ}$, inciso VII, da Lei de Diretrizes e Bases da Educação Nacional (LDB), verifica-se que o termo "gestão" é enfatizado como um dos princípios que devem reger o ensino. A lei coloca a necessidade de que a gestão das escolas se realize por meio de processos coletivos, abrangendo a participação da comunidade local e escolar, sendo este o princípio da gestão democrática:

A gestão democrática exige o cultivo da cultura da participação, do trabalho coletivo, da ação colegiada, da realização pelo bem comum. Enfim, é preciso possibilitar momentos de experimentação da democracia na escola para se tornar uma prática efetiva, consolidada e possível de ser efetivamente vivenciada (PEREIRA; OLIVEIRA, 2006 apud BUZO; MACHADO, 2010, p. 103).

O Ministério da Educação (2004) aponta que, para haver a gestão democrática, é necessário que se efetivem novos processos de organização e gestão, de modo que promovam os processos coletivos e participativos de decisão.

Se a verdadeira democracia caracteriza-se, dentre outras coisas, pela participação ativa dos cidadãos na vida pública, considerados não apenas como "titulares de direito", mas também como "criadores de novos direitos", é preciso que a educação se preocupe com dotar-lhes das capacidades culturais exigidas para exercerem essas atribuições, justificando-se, portanto, a necessidade de a escola pública cuidar, de forma planejada e não apenas difusa, de uma autêntica formação do democrata (PARO, 2006, p. 78). 
Para que a organização e a gestão democrática se efetivem na escola, é necessário haver uma gestão que planeje, organize, dirija e avalie a instituição como um todo, ou seja, não somente na administração, mas também na integração das atividades das pessoas que atuam na escola.

Dessa forma, a construção da gestão democrática não pode ser individual, mas coletiva, abrangendo os diversos atores para discutir e tomar decisões, sendo que para a prática do processo de democratização na escola há a necessidade de um

[...] redirecionamento dos novos marcos de gestão em curso, cuja ênfase recai sobre novos procedimentos e transparências nas ações. A esse respeito, ressalta-se, no âmbito das políticas educacionais voltadas para a educação básica, a noção de autonomia imputada às escolas, traduzida na noção das escolas enquanto núcleo de gestão, cuja máxima reside na possibilidade de a instituição se organizar, sobretudo por meio de órgão consultivos e deliberativos que contem com participação de representantes de todos os segmentos da comunidade local e escolar, de forma a pensar, planejar, elaborar e implementar seus projetos (OLIVEIRA; MORAES; DOURADO, 2010, p. 06).

Assim, segundo Cury (2010, p. 22), a gestão democrática da educação é

Ao mesmo tempo, por injunção da nossa Constituição (art. 37): transparência e impessoalidade, autonomia e participação, liderança e trabalho coletivo, representatividade e competência. Voltada para um processo de decisão baseado na participação e na deliberação pública, a gestão democrática expressa um anseio de crescimentos dos indivíduos como cidadãos e do crescimento da sociedade enquanto sociedade democrática. Por isso a gestão democrática é a gestão de uma administração concreta.

Gestão democrática consiste, assim, na garantia da participação efetiva de todos os sujeitos envolvidos com as instituições escolares. Pais, funcionários e comunidade devem estar cientes da necessidade e da importância de sua participação junto a todos os processos de decisão que envolvem a escola e, para tanto, necessitam do maior acesso às informações. 
Afora isso, a Constituição Federal de 1988 estabelece como um dos seus princípios a gestão democrática das escolas públicas e também o acesso à escola e a garantia de padrão de qualidade a todos. A Lei de Diretrizes e Bases (1996), por seu turno, cita a gestão da educação quando determina os princípios que devem reger o ensino, indicando, assim, a gestão democrática:

Art. 14. Os sistemas de ensino definirão as normas de gestão democrática do ensino público na educação básica, de acordo com as suas peculiaridades e conforme os seguintes princípios:

I - Participação dos profissionais da educação na elaboração do projeto político pedagógico da escola;

II - Participação das comunidades escolar e local em Conselhos Escolares ou equivalentes (BRASIL, 1996).

A gestão democrática da escola, nesse contexto, pressupõe as decisões coletivas da maioria das pessoas que a integram. A gestão democrática da escola é, portanto, o processo político que nela se organiza, garantindo a participação de todos os que participam direta ou indiretamente da educação - professores, funcionários, famílias, alunos, comunidade -, respeitando sempre a vontade da maioria dessas pessoas.

Pensarmos a democratização implica, portanto, compreendermos a cultura da escola e dos seus processos, bem como articulá-los com as relações sociais mais amplas. A compreensão dos processos culturais na escola envolve diretamente os diferentes segmentos das comunidades locais e escolar, seus valores, atitudes e comportamentos. Ou seja, a escola é um espaço de contradições e diferenças. Nesse sentido, quando buscamos construir na escola um processo de participação baseado em relações de cooperação, no trabalho coletivo e no partilhamento do poder, precisamos exercitar a pedagogia do diálogo, do respeito às diferenças, garantindo a liberdade de expressão, a vivência de processos de convivência democrática, a serem efetivados no cotidiano, em busca da construção de projetos coletivos (BRASIL, 2004, p. 26).

Não se pode afirmar que a escola passe a ser uma instituição democrática se não houver preocupação dos agentes educacionais para o que seja a construção do processo 


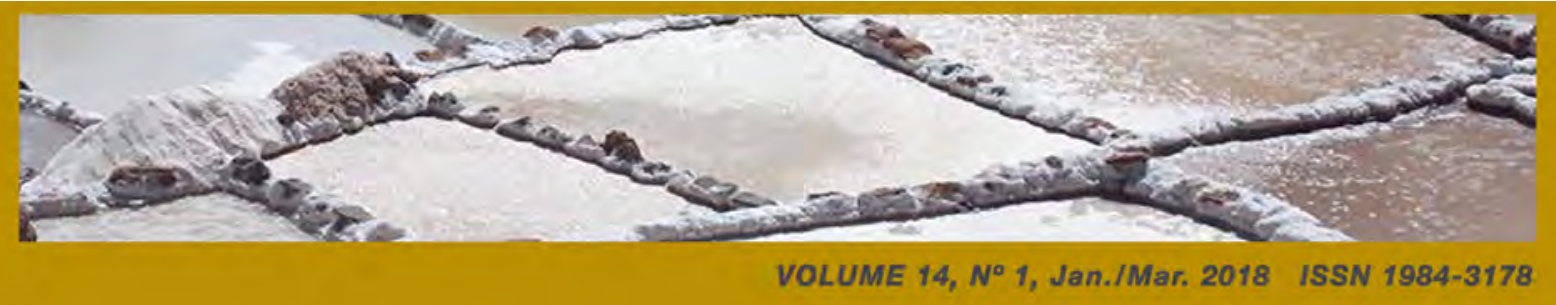

democrático no cotidiano da escola. É necessário que a gestão democrática seja incorporada e se torne essencial à vida escolar, assim como é a presença de professores e alunos. Segundo Libâneo (2004), para haver a legitimação da educação democrática, é necessário que haja autonomia na educação, valorizando a identidade cultural, a aprendizagem e participação de todos, promovendo a inclusão e a formação de cidadãos ativos em nossa sociedade. Devemos estar atentos à ideologia que subjaz as legislações que regem o nosso ensino, no sentido da garantia do direito a uma educação democrática e de qualidade, em que todos, independentemente de raça, religião ou posição social, tenham o mesmo nível de educação.

A gestão escolar deve ter clareza sobre o que almeja futuramente. Identificar os saberes necessários a uma prática pedagógica contextualizada com as realidades atuais é fundamental para construir um modelo educacional de qualidade. Na busca da formação de uma gestão democrática e participativa, a autonomia das instituições escolares é fundamental.

Quanto à autonomia das escolas, Buzo e Machado (2010, p. 104) citam que

Um dos objetivos e prioridades expressos no Plano Nacional de Educação (PNE), lei aprovada em janeiro de 2001, é a democratização da gestão do ensino público nos estabelecimentos oficiais, e uma de suas metas é a criação de Conselhos Escolares nas escolas de educação infantil, ensino fundamental e ensino médio. A Lei de Diretrizes e Bases da Educação Nacional (LDB), em seu artigo 14, estabelece que os sistemas de ensino definirão as normas da gestão democrática do ensino público na educação básica, de acordo com as suas peculiaridades e conforme os seguintes princípios: participação dos profissionais da educação na elaboração do projeto pedagógico da escola, participação das comunidades escolar e local e Conselhos Escolares ou equivalentes.

Ainda nos reportando a leis, Buzo e Machado (2010) elencam que a Constituição Federal, em seu artigo 205, expressa que "a educação, direito de todos e dever do Estado e da família, será promovida e incentivada com a colaboração da sociedade, visando ao pleno desenvolvimento da pessoa, seu preparo para o exercício da cidadania e sua qualificação para o trabalho". No artigo 206, fica expresso que o ensino será ministrado com base em alguns princípios, entre eles a gestão democrática do ensino público, na forma da lei. 


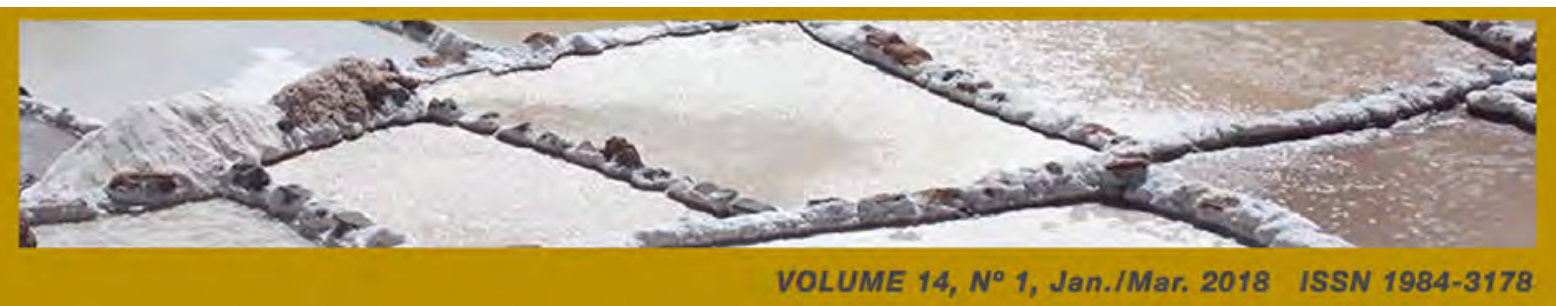

Veiga (1988), ao discutir a autonomia da escola, destaca quatro dimensões básicas para o funcionamento de uma escola e afirma que estas devem ser relacionadas e articuladas entre si, conforme segue:

\begin{abstract}
Autonomia Administrativa - consiste na possibilidade de elaborar e gerir seus planos, programas e projetos; Autonomia Jurídica - diz respeito à possibilidade de a escola elaborar suas normas e orientações escolares em consonância com as legislações educacionais, como, por exemplo, matrícula, transferência de alunos, admissão de professores, concessão de grau; Autonomia Financeira - refere-se à disponibilidade de recursos financeiros capazes de dar à instituição educativa condições de funcionamento efetivo; Autonomia Pedagógica - consiste na liberdade de propor modalidades de ensino e pesquisa. Está estreitamente ligada à identidade, à função social, à clientela, à organização curricular, à avaliação, bem como aos resultados e, portanto, à essência do projeto pedagógico da escola (VEIGA, 1998 apud OLIVEIRA; MORAES; DOURADO, 2010, p. 09, grifo do autor).
\end{abstract}

Essa autonomia, entretanto, não exclui a participação do Estado, de membros da escola e da comunidade, pelo contrário, delega a todos a sua função. Assim, é de fundamental importância a ação em rede de todos os envolvidos e o entendimento do papel de cada um para contribuir com o coletivo, pois:

O conceito de participação se fundamenta no de autonomia, que significa a capacidade das pessoas e dos grupos de livre determinação de si próprio, isto é, de conduzirem sua própria vida. Como autonomia opõe-se às formas autoritárias da tomada de decisão, sua realização concreta nas instituições é a participação (LIBÂNEO, 2004, p. 26).

No entanto, se a autonomia das pessoas e dos grupos não for respeitada, a participação poderá se comprometer, deixando a democracia de lado e se confundindo com o autoritarismo. Para possibilitar a participação, a escola, por meio do gestor escolar, deve abrir suas portas para a promoção efetiva da participação da comunidade com o objetivo de construir o espaço escolar que almejamos, possibilitando, aos cidadãos, o entendimento e a identidade de um novo espaço na gestão escolar. Segundo as concepções de Farfus (2008), 


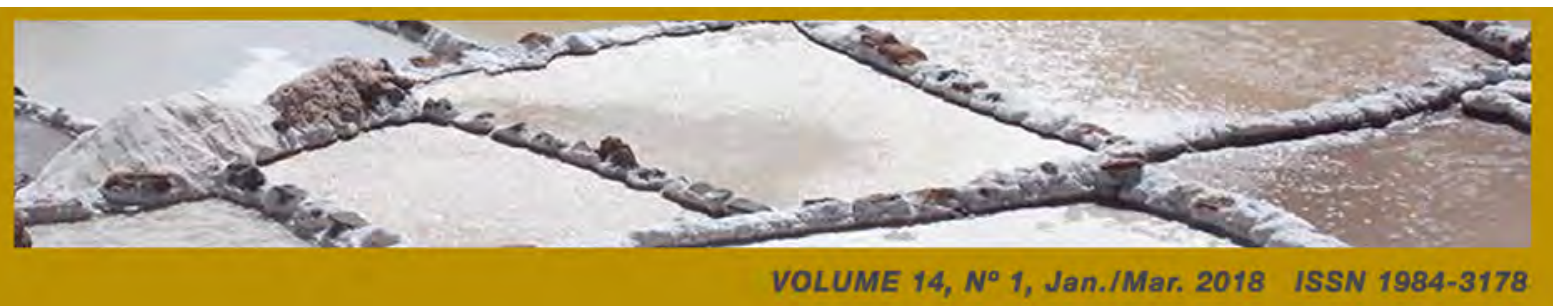

O perfil do gestor escolar deve ser de tal forma que atenda às demandas sociais, articule a escola com outras organizações, promova um ensino de qualidade, realize uma avaliação objetivando realimentação contínua, sistematize propostas integradas e linhadas a concepções contemporâneas que forneçam um indivíduo que viva sua cotidianidade (FARFUS, 2008, p. 28).

A mudança nos conceitos, nas atitudes, com maior valorização da figura humana, é um dos fatores principais para que possamos construir, planejar e idealizar um futuro próspero para nossas instituições escolares. Elas devem ser, portanto, espaços que promovam a oportunidade do exercício da democracia,

\begin{abstract}
Mas é preciso considerar que, na condição de uma instituição social, cada escola desenvolve ritos e práticas exercidos pelos atores que, no seu interior, ou mesmo no seu entorno, desempenham papéis e funções distintos: grupo de gestores, professores, alunos, funcionários, pais, comunidade. De um lado, esses ritos e práticas possuem uma direta vinculação com a história da escola, com as características da comunidade em que se insere, com as formas de percepção da realidade dos que a fazem e das relações que estabelecem entre si. De outro lado, é a institucionalização daquelas práticas que torna a escola uma instituição social, forjando as regras pelas quais ela exerce os seus papéis fundamentais: criação e transmissão de saberes, socialização dos futuros cidadãos, desenvolvimento de competências profissionais, tudo de acordo com seus limites e possibilidades (AZEVEDO, 2010, p. 02).
\end{abstract}

A intenção de construir uma escola democrática, na qual os cidadãos exercerão plenamente sua cidadania a partir da compreensão de que estão efetivamente incluídos nessa sociedade, requer o desenvolvimento de novas formas de gestão, como a efetivação dos conselhos escolares.

Segundo Navarro (2004), a efetivação da gestão democrática é um processo de vivência e aprendizado. Há, portanto, a necessidade de que sejam oportunizadas condições concretas para o seu exercício, o que implica, principalmente, a construção cotidiana e permanente de um sujeito capaz de atuar nesse modo de fazer pedagógico, tendo em vista uma finalidade comum: a vivência democrática. 


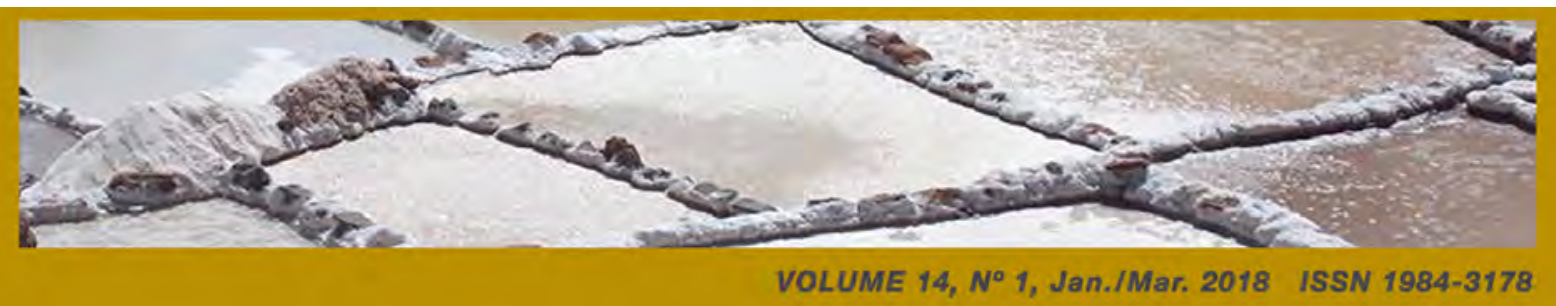

Ao gestor, compete a tarefa de conduzir as ações da comunidade escolar que objetivam motivar as pessoas envolvidas no processo de construção da qualidade do ensino público, no sentido de perceberem que são responsáveis e comprometidas com o projeto político-pedagógico da escola e o Conselho Escolar.

A gestão democrática exige o cultivo da cultura da participação, do trabalho coletivo, da ação colegiada, da realização pelo bem comum. Enfim, é preciso possibilitar momentos de experimentação da democracia na escola para se tornar uma prática efetiva, consolidada e possível de ser efetivamente vivenciada (PEREIRA; 2006 apud MACHADO, 2010, p. 103).

Souza et al. (2005) afirmam que precisamos, portanto, mesmo que do ponto de vista apenas metodológico,

Apresentar a ideia de gestão democrática como sendo o processo político através do qual as pessoas na escola discutem, deliberam e planejam, solucionam problemas e os encaminham, acompanham, controlam e avaliam o conjunto das ações voltadas ao desenvolvimento da própria escola. Este processo, sustentado no diálogo e na alteridade, tem como base a participação efetiva de todos os segmentos da comunidade escolar, o respeito a normas coletivamente construídas para os processos de tomada de decisões e a garantia de amplo acesso às informações aos sujeitos da escola $(2005, \mathrm{p}$. $15)$.

A escola pública, em todos os níveis da educação básica, tem como função social formar o cidadão para que ele interaja com o mundo em que vive.

A escola pública poderá, dessa forma, não apenas contribuir significativamente para a democratização da sociedade, como também ser um lugar privilegiado para o exercício da democracia participativa, para o exercício de uma cidadania consciente e comprometida com os interesses da maioria socialmente excluída ou dos grupos sociais privados dos bens culturais e materiais produzidos pelo trabalho dessa mesma maioria. A contribuição significativa da escola para a democratização da sociedade e para o exercício da democracia participativa fundamenta e exige a gestão democrática na escola (BRASIL, 2004, p. 20). 
A gestão democrática na escola pública é algo possível de se construir no cotidiano, na relação respeitosa com os outros, que constituem a razão de ser da escola, o aluno, o pai, a mãe, o professor, a professora, o auxiliar administrativo, o vigia, o auxiliar de serviço, representantes da comunidade em torno, enfim, de todos os seres humanos em qualquer situação que se encontrem.

Na Gestão Democrática, pretende-se a superação de tradições autoritárias e se aposta no envolvimento de todos, o que requer transparência de ações, divisão de poder e corresponsabilização pelos erros e acertos. Requer também definições claras de objetivos, opções ético-políticas e limites de ação (SILVA, 2002 apud SILVA, 2010, p. 02).

A democracia, para Bobbio (2000 apud SOUZA, 2009, p. 129), é algo instrumental que estabelece "Um conjunto de regras de procedimento para a formação de decisões coletivas, em que está prevista e facilitada a participação mais ampla possível dos interessados".

Assim, quando as pessoas do universo escolar adotam a democracia e o diálogo não só nas relações na escola, porém como um alicerce de vida nas esferas da sociedade,

[...] conseguem transpor a esfera do desejado, implementando o princípio, transformando-o em método ou, pelo menos, em agenda, tanto na organização da educação/escola quanto na pesquisa, na medida em que as escolas (como instituições destinadas à formação humana) e as pesquisas sobre a gestão escolar têm o dever de colocar em pauta os problemas e as alternativas de enfrentamento a esses problemas organizacionais e políticos, histórica e contemporaneamente. (SOUZA, 2009, p. 14).

O exercício da gestão democrática na escola, por conseguinte, não é mais só necessária, é vital, porque é questão de sobrevivência construir consciências críticas, participativas que fazem e sabem por que fazem. Caso contrário, a escola produzirá seres inaptos para o trabalho, para a vida. 


\subsection{CONSELHOS ESCOLARES E PROJETO POLÍTICO-PEDAGÓGICO}

A Lei complementar $n^{\circ}$ 170/1998 trata do Sistema Estadual de Educação, e nela consta a questão da gestão democrática. O Conselho Deliberativo Escolar afirma, em seu art. 20, parágrafo II, as atribuições das escolas:

II - entre outras atribuições do Conselho Deliberativo Escolar recomendadas pelo porte da escola ou pela ação governamental a ser desenvolvida, devem constar as seguintes:

fiscalização do plano de aplicação de recursos financeiros vinculados repassados à escola; b) deliberação prévia sobre a aplicação de recursos financeiros não vinculados repassados à escola; c) participação na elaboração do projeto político-pedagógico da escola e do calendário escolar anual ou em suas alterações (BRASIL, 1998).

Nessa mesma direção, o Decreto $n^{0} 3.429$, de 08 de dezembro de 1998, em seu art. $2^{\circ}$, regulamenta os passos a serem seguidos nos estabelecimentos de ensino de educação básica da rede pública estadual:

Art. 2. ${ }^{\circ}$ - O Conselho Deliberativo Escolar, vinculado ao corpo diretivo da escola, será formado por representantes de todos os segmentos da comunidade escolar, constituindo-se em agente de participação na construção da gestão democrática da escola.

Parágrafo único. Nas suas ações de natureza avaliativa e deliberativa, o Conselho Deliberativo Escolar se norteará pelos princípios constitucionais, normas legais vigentes, políticas educacionais e diretrizes emanadas dos órgãos do sistema.

Com base na mesma reflexão, na Portaria $n^{0}$ 008/99, de 27 de maio de 1999, a Secretária de Estado da Educação e do Desporto, tendo em vista a lei complementar e o decreto já citados, resolve, em seu art. 2. ${ }^{\circ}$ : 


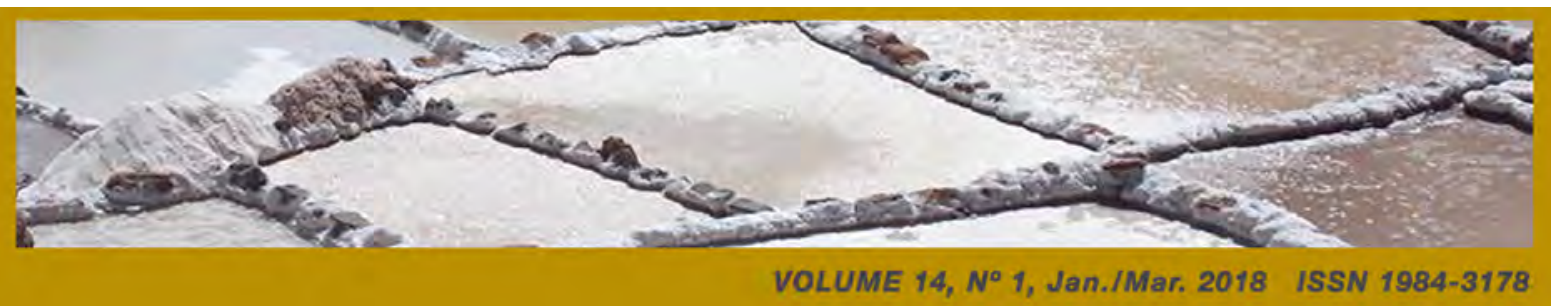

Art. $2^{\circ}$ - O Conselho Deliberativo Escolar tem a finalidade de assegurar a participação de todos os segmentos da comunidade escolar na gestão democrática, com funções de caráter consultivo, normativo, deliberativo e avaliativo, e visa promover o fortalecimento da autonomia pedagógica, administrativa e financeira das Unidades Escolares.

$\S 1^{\circ}$ - Entendem-se por segmentos da comunidade escolar os alunos, pais e mães ou responsáveis legais por aluno, membros do magistério (professores e especialistas em assuntos educacionais) e servidores (SANTA CATARINA, 1998).

Ainda em seu artigo $2^{\circ}$, no parágrafo $2^{\circ}$, o texto explica que o Conselho Deliberativo deve exercer as funções de caráter consultivo, normativo, deliberativo e avaliativo. Verificase, assim, que a implantação do Conselho Escolar garantirá uma gestão mais democrática, pois exercerá uma maior capacidade de fiscalização e controle da sociedade civil sobre a execução da política educacional. Propiciando uma legitimidade nas ações desenvolvidas pela escola, haverá mais transparência das decisões tomadas, garantindo assim, um espaço para que todos os segmentos da comunidade escolar possam expressar suas ideias e necessidades, contribuindo para as discussões dos problemas e a busca de soluções:

O Conselho Escolar se configura, portanto, como órgão de representação da comunidade escolar e, desse modo, visa à construção de uma cultura de participação, constituindo-se em espaço de aprendizado do jogo político democrático e de formação político-pedagógica. Por essa razão, a consolidação dos conselhos escolares implica buscar a articulação efetiva entre os processos pedagógicos, a organização da escola e o financiamento da educação e da escola propriamente dito (OLIVEIRA; MORAES; DOURADO, 2010, p. 03).

Um Conselho Escolar bem articulado deve, juntamente com o gestor, desenvolver um trabalho que interligue a escola com a comunidade e com o mundo, propiciando aos educadores e educandos caminhos e estratégias que criem alternativas pedagógicas, administrativas e sociais.

O Conselho Escolar deve, portanto, tomar conhecimento e participar na reelaboração ou elaboração dos principais documentos que norteiam as ações da escola, e o PPP - Projeto Político Pedagógico, documento esse que rege as ações da escola e que deve ser construído de 


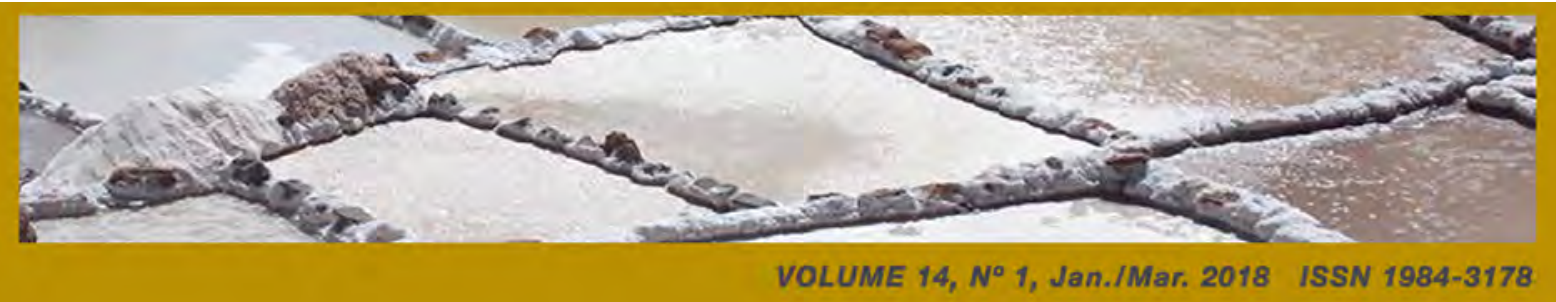

maneira coletiva e participativa pela comunidade escolar. Segundo Veiga (2003, p. 9), “O projeto político pedagógico dá o Norte, o rumo, a direção; ele possibilita que as potencialidades sejam equacionadas, deslegitimando as formas instituídas".

Isso tudo propicia espaços para uma construção e para uma tomada de decisões coletivas, criando condições político/pedagógicas para o desenvolvimento do potencial de cada indivíduo, comprometendo-se com a comunidade escolar. Fonseca (2003) situa o projeto político pedagógico como:

Uma proposta nacional que incentiva a escola a traçar seu próprio caminho educativo, destacando a importância da participação dos profissionais da educação em colegiados escolares, na intenção de superar a gestão de meios e produtos, apelando para iniciativas orientadas para o que é humanamente bom, e que levem em conta a cultura, as condições de vida do local e a qualificação dos professores (FONSECA, 2003 apud CASTRO; WERLE, 2005, p. 192).

Segundo Azevedo (2010), é inegável a importância do projeto pedagógico, particularmente quando se assume o seu significado como projeto político-pedagógico (PPP), o que ocorre quando o seu processo de elaboração e implementação se pauta pelo princípio democrático da participação e, portanto, como um dos elementos do exercício da gestão escolar democrática. Desse ponto de vista, o PPP é também um instrumento fundamental para a efetiva construção e instalação da democracia social entre nós, pois envolve a articulação direta desta com as práticas de participação social. Ou seja, é necessário que a maioria das instituições sociais, incluindo os serviços públicos e a escola, seja democraticamente governada.

A efetivação de uma nova relação entre a educação, a escola e a democracia constitui um aprendizado político-pedagógico cotidiano que requer a implementação de novas formas de organização e participação interna e externamente à escola. Ou seja, a construção de uma educação emancipatória e, portanto, democrática se constrói por meio da garantia de novas formas de organização e gestão, pela implementação de mecanismos de distribuição do poder, que só é possível a partir da participação ativa dos cidadãos na vida pública, articulada à necessidade de formação para a democracia (BRASIL, 2004, p. 29). 


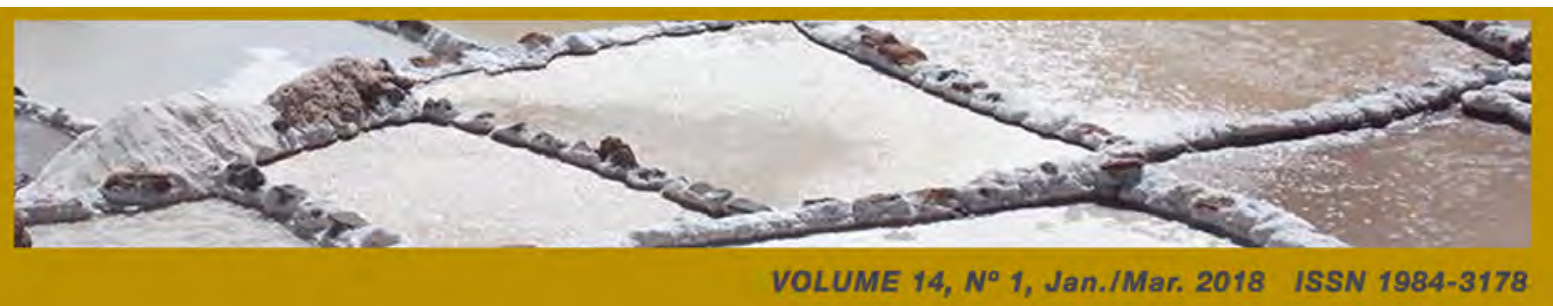

Nesse sentido, o PPP constitui-se o caminho/busca de uma nova direção e de um novo sentido, por meio de forças internas e externas favoráveis à compreensão da escola que temos e a construção da escola que queremos.

De acordo com a LDB 9394/96, determinou-se, dentre as incumbências dos sistemas públicos, que estes devem definir as normas da gestão democrática do ensino básico, com a garantia da participação dos profissionais da educação na elaboração do Projeto Pedagógico da escola e da participação das comunidades escolar e local em conselhos escolares ou equivalentes.

\begin{abstract}
É inegável a importância do projeto pedagógico, particularmente quando se assume o seu significado como projeto político-pedagógico (PPP), o que ocorre quando o seu processo de elaboração e implementação se pauta pelo princípio democrático da participação e, portanto, como um dos elementos do exercício da gestão escolar democrática. Desta perspectiva, o PPP é, também, um instrumento fundamental para a efetiva construção e instalação da democracia social entre nós. Isto significa dizer que a democracia não se limita à sua dimensão política, pois envolve a articulação direta desta com as práticas de participação social. Ou seja, é necessário que a maioria das instituições sociais, incluindo os serviços públicos e a escola, seja democraticamente governada (AZEVEDO, 2010, p. 02).
\end{abstract}

Consideramos um ponto muito relevante a questão dos próprios membros, através dos estudos perceberem a importância de envolver toda a comunidade no ambiente escolar, não somente na questão financeira, mas principalmente na pedagógica. Diante dessa consciência, a busca pelo conhecimento não se torna uma imposição do grupo, mas a partir do sentimento de necessidades dos membros do conselho. Esse é um grande passo na construção da cidadania e de uma gestão democrática. A busca pela verdadeira democracia, com a participação real de todos - e temos consciência de que ainda há muito caminho a percorrer para que se encontre êxito ao final. Democracia esta que deve estreitar os laços entre educador, educadores, sujeitos da educação. 


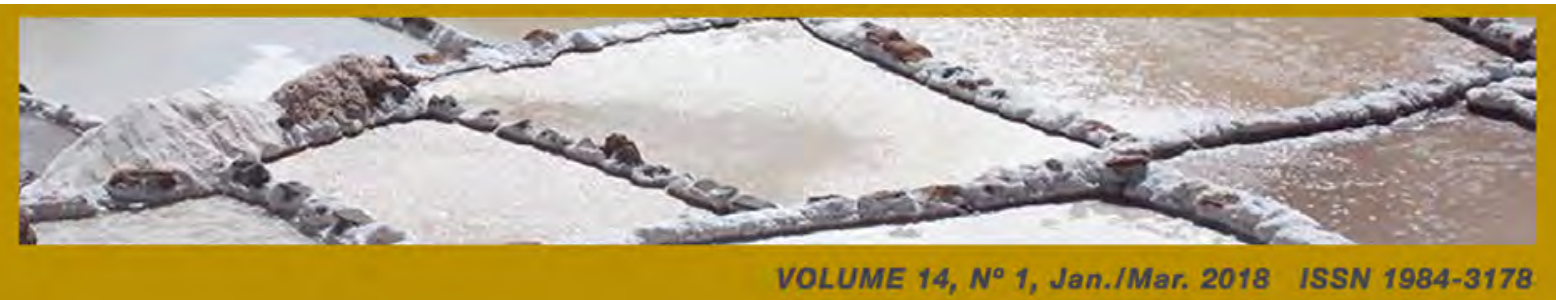

\section{O CONSELHO ESCOLAR NO CENTRO EDUCACIONAL MUNICIPAL SÃO CRISTOVÃO}

Devido à determinação da Secretaria Municipal da Educação, o Centro de Educação Municipal São Cristóvão formou em 28/10/2009 o Conselho Escolar da Educação, em substituição à Associação de Pais e Professores (APP).

A Secretaria Municipal forneceu o estatuto de funcionamento e a informação de que ele viria em substituição à Associação de Pais e Professores, que, além de fazer o mesmo trabalho que a APP, desenvolvia, como diferencial o seu envolvimento nas questões pedagógicas, devendo a escola fazer esse trabalho de formação e orientação dos Conselheiros.

\subsection{PROJETO DE INTERVENÇÃO E CARACTERIZAÇÃO DA ESCOLA}

A escola São Cristóvão, fundada em 21 de fevereiro de 1958, quando pertencia ao município de Curitibanos com o nome de Escola Municipal Cerro do Bugio, teve suas atividades desenvolvidas em uma capela cedida pela comunidade até 01 de abril de 1961 . Após essa data, passou a ser escola estadual, onde, neste ano, foi construído um espaço físico próprio, de madeira, com uma área de $48 \mathrm{~m}^{2}$. Ainda neste mesmo ano, com o Decreto Lei $\mathrm{n}$. 797, que criou o município de Fraiburgo, a escola passou a pertencer a este município.

A partir do mês de maio de 1998, a escola passou a se denominar Escola Municipal São Cristóvão. Essa mudança, que aconteceu pelo Decreto Lei n. ${ }^{\circ} 2.344$, do dia 21 de outubro de 1997, transfere as escolas estaduais para os municípios.

A escola atende hoje 150 alunos, distribuídos em 09 turmas: Berçário I e II, maternal com período integral e as demais turmas divididas em períodos matutinos e vespertinos, sendo Jardim I e II, Pré-escola, $1^{\circ}$ ano, $2^{\circ}$ ano, $3^{\circ}$ ano, $4^{\circ}$ ano e $4^{\mathrm{a}}$ série.

O Centro Educacional Municipal São Cristóvão conta com cinco profissionais com formação de ensino médio, 01 profissionais com graduação em pedagogia e 12 profissionais com pós-graduação e especialização na área, totalizando 18 profissionais. O espaço físico é composto de seis salas de aula, uma biblioteca, uma sala de informática, uma sala de professores, secretaria, um depósito, uma cozinha, cinco banheiros e um parquinho. 


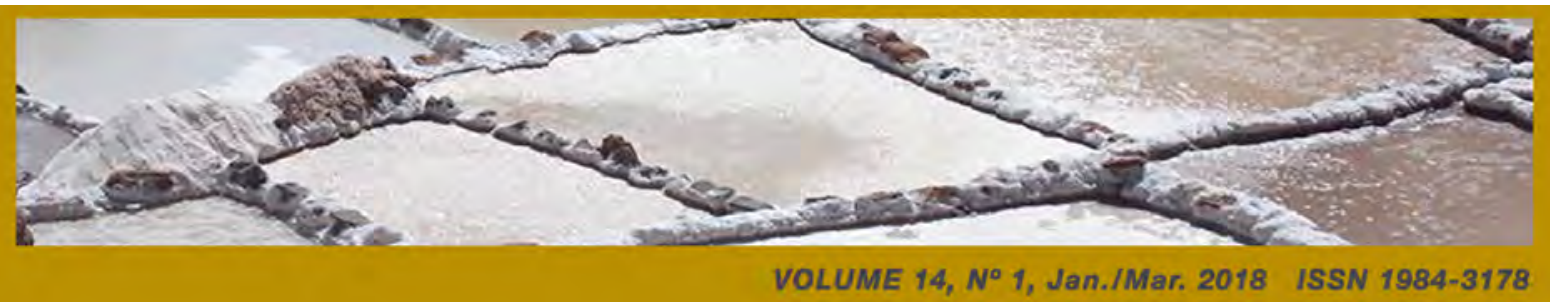

As tecnologias presentes na escola são computadores, máquina copiadora, aparelho de DVD e vídeo, antena parabólica, retroprojetor, mimeógrafo, aparelhos de som e TV. A utilização é de acordo com a necessidade de cada professor, estando estes equipamentos sempre à disposiç̧ão.

\section{DESENHO DO ESTUDO}

O Projeto de Intervenção foi realizado no período de junho 2009 a junho de 2010, com o objetivo de fortalecer e orientar o Conselho Escolar no Centro Educacional Municipal São Cristovão.

As estratégias de ação propostas foram:

- Organizar palestras com o grupo escolar para desenvolver o sentimento de pertença;

- Promover encontros para estudar as legislações que regem os encontros escolares através de estudos dos cadernos sobre conselhos escolares e do Estatuto do Conselho Escolar Municipal;

- Reunir os membros para definir as atribuições do Conselho Escolar constantes no Estatuto do Conselho Escolar, conhecendo, assim, os deveres e direitos dos conselheiros;

- Confeccionar cartazes informativos sobre o Conselho Escolar para serem trabalhados na escola;

- Promover encontros periódicos dos conselheiros para discutir as prioridades da escola;

- Elaborar relatórios sobre as atividades na escola, para que toda a comunidade escolar tenha acesso à dinâmica educativa desenvolvida;

- Avaliar continuamente, pelos membros do Conselho, as necessidades e o desempenho do Conselho Escolar, para que seja revisto o que for preciso para o bom andamento da comunidade escolar;

- Integração do Conselho Escolar ao projeto político-pedagógico. 


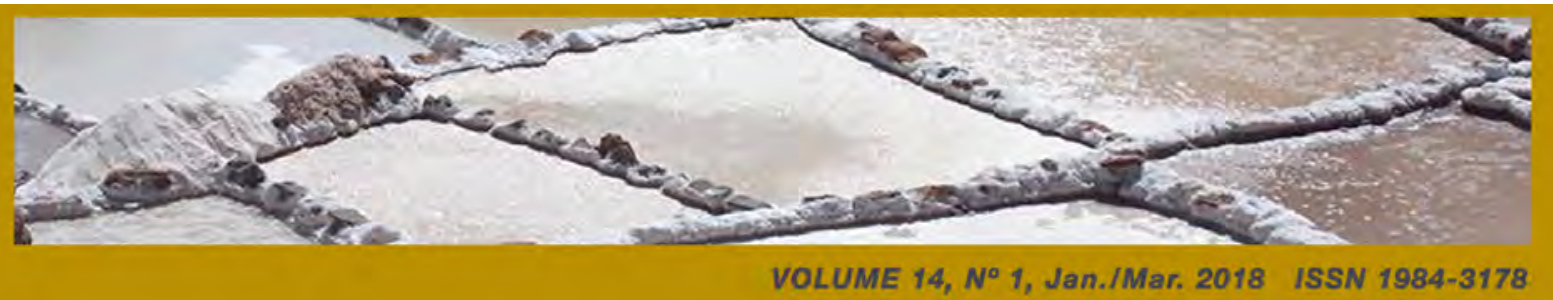

Essas estratégias foram desenvolvidas durante a aplicação do Projeto de Intervenção no Centro Educacional Municipal São Cristóvão.

A partir de dados obtidos do estudo empírico, foi realizada uma análise teóricoreflexiva, partindo-se de um Projeto de Intervenção já aplicado, com o recorte "Conselho Escolar e PPP”.

Pretendeu-se mostrar a importância do Conselho Escolar na escola e para a comunidade escolar, pois há a necessidade de conhecermos o seu respaldo legal, a função de cada membro, a formação e organização da funcionalidade e as ações que esse conselho pode vir a fazer para que exerça um papel significativo diante da educação.

Foram utilizados os resultados obtidos com a aplicação do Projeto de Intervenção, tais como debates, reelaboração do PPP, apresentados descritivamente. Faremos um relato aproveitando o texto do PI, enfatizando o que mais interessa aqui: Conselho Escolar e PPP.

O Conselho Escolar iniciou-se, a partir do ano de 2010, no Centro Educacional Municipal São Cristóvão, um órgão efetivo que aproxima a escola da comunidade, de maneira que contribua para uma gestão democrática e transparente. Formado o Conselho, houve a necessidade de entender como ele deve funcionar e qual a sua contribuição para a unidade escolar.

Por ser algo novo em nossa escola, havia muitas dúvidas com relação ao funcionamento do Conselho. Como é uma escola de um bairro pequeno e de interior, que conta com um número relativamente pequeno de alunos, primeiramente, deixou-se em aberto como convite a quem da comunidade escolar se interessasse em participar da formação do Conselho Escolar.

No entanto, houve pouca manifestação espontânea, sendo alguns convites direcionados a pessoas que já eram conhecidas e ativas na comunidade escolar, alguns já membros da antiga Associação de Pais e Professores (APP). Ressaltamos que essas pessoas foram aceitas de maneira democrática por todos os presentes na assembleia geral:

Na Gestão Democrática, pretende-se a superação de tradições autoritárias e aposta-se no envolvimento de todos, o que requer transparência de ações, 


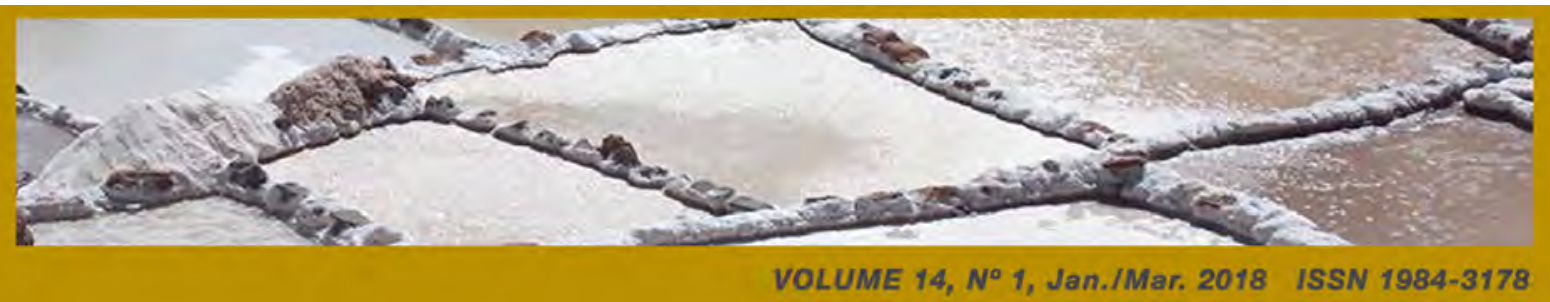

divisão de poder e corresponsabilização pelos erros e acertos. Requer também definições claras de objetivos, opções ético-políticas e limites de ação (SILVA, 2002 apud SILVA, 2010, p. 02).

A democracia, segundo Silva (2010, p. 2) é “Algo instrumental que estabelece um conjunto de procedimentos para a formação de decisões coletivas, sendo facilitada a participação mais ampla possível dos interessados".

No Plano Nacional de Educação (BRASIL, 2004 p. 18), há esclarecimentos sobre os objetivos das políticas da educação, destacando-se que se refere à existência dos conselhos escolares: “A participação dos profissionais da educação na elaboração do projeto pedagógico da escola e a participação das comunidades escolar e local em conselhos escolares ou equivalentes".

De acordo com a legislação vigente, o processo de construção das propostas pedagógicas deve prever a participação da comunidade. E quando se dá essa oportunidade de construção coletiva, todos se tornam responsáveis pelo seu sucesso, comprometendo-se com a implantação, desenvolvimento e a avaliação.

A construção de uma escola democrática implica uma forma de gestão preocupada com a participação de todos os membros da comunidade escolar, alunos e seus pais, professores, funcionários e direção. Paro (2006) compreende que a administração escolar democrática

[...] em sua forma democrática e cooperativa, não é algo pronto, que se possa aplicar como uma receita [...]. Embora se tenha presente que a autoridade deva ser compartilhada por todos, o que supõe formas coletivas ou colegiadas de gestão escolar, não é possível estabelecer a priori, com precisão, qual a forma mais adequada dessa administração [grifos do autor] (p. 161).

Uma gestão democrática pressupõe, portanto, a constituição de mecanismos de participação, a exemplo dos colegiados, que devem assumir funções de apoio à direção, de 


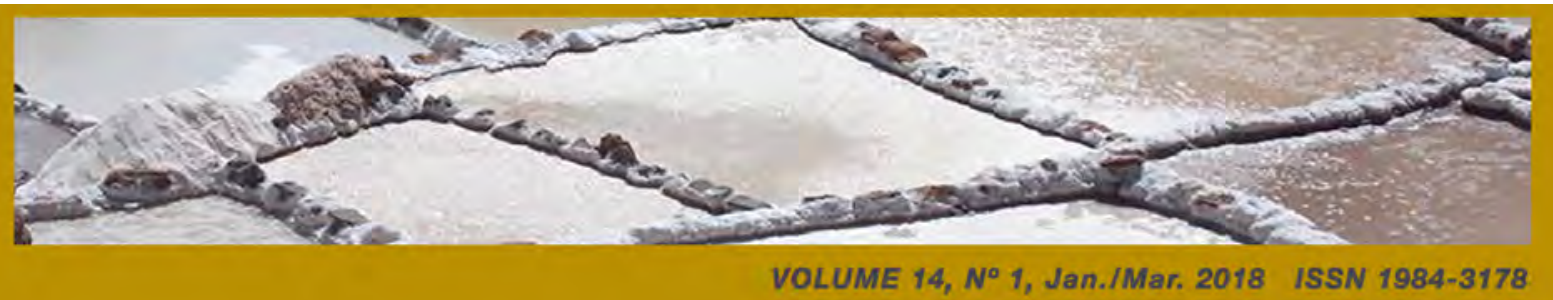

consulta quanto à sua opinião e de participação nas discussões sobre assuntos que dizem respeito ao cotidiano escolar.

Na busca da qualidade da educação para todos, a fiscalização e a avaliação das ações devem ser constantes. Verificar as prioridades das escolas, não só referentes à estrutura, mas também aos componentes dela, deve ser o primeiro passo para se buscarem caminhos para a resolução dos problemas.

O espaço educacional, com a existência de uma comunidade, transforma-se em um espaço de construção de um trabalho articulado entre diversas organizações. O Conselho Escolar tem o objetivo de facilitar essa articulação, no sentido de se desenvolver um trabalho que possibilite a produção de uma nova cultura, fundamentada no sentimento de fazer parte de uma família, de uma escola, de uma nação. Uma cultura que fortaleça ações e relações, desenvolvendo a cidadania.

Diante disso, percebe-se que a educação esteve sempre para atender às necessidades do sistema vigente. Essa incessante demanda acaba determinando a forma como ocorre a gestão e o trabalho dentro de nossas escolas. Como a nossa está situada num bairro carente, percebe-se que muitos dos pais de nossos alunos não sabem de que forma intervir eficazmente em nossa instituição.

Não queremos, entretanto, que o Conselho seja mais um nome bonito, em que a direção dite as regras e os demais membros consintam sem questionar. Por isso, há a necessidade de se oferecer uma formação continuada, momentos de debates e outros para que todos tenham acesso às decisões tomadas e às ações promovidas, para que, com certeza, elas sejam tomadas de maneira democrática e inclusiva. Nessa direção, foram elaboradas estratégias de ação.

\subsection{AÇÕES DESENVOLVIDAS COM A COMUNIDADE ESCOLAR}

Foram organizadas palestras com o grupo escolar, sendo envolvidos alunos, pais, professores e funcionários. Esses encontros esclareceram à comunidade o papel importante que o Conselho Escolar tem na questão pedagógica do aluno, assumindo-se o compromisso com o desenvolvimento de uma educação básica competente, em que a proximidade com o 


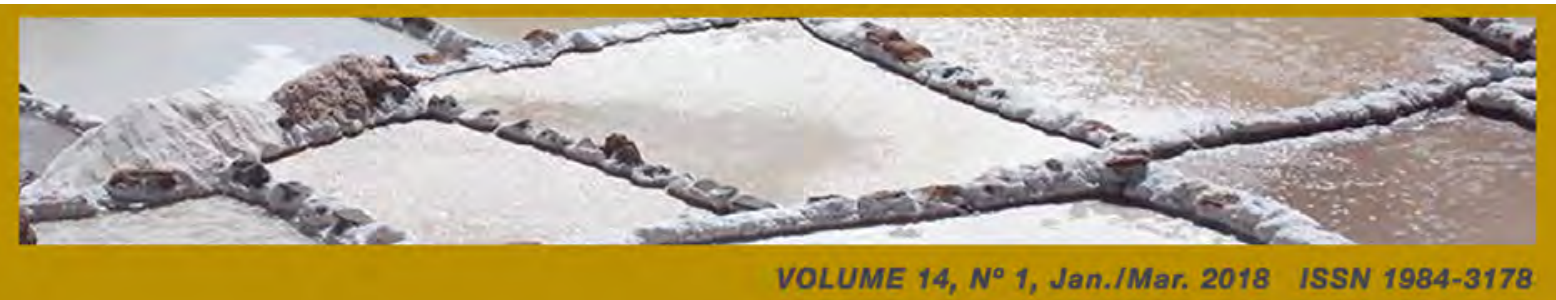

saber científico de forma significativa seja a base para a formação de um cidadão crítico e criativo, em que o ato de ensinar não se dê através de situações prontas, fechadas, definitivas, mas, sim, como processo de reflexão contínua sobre as inúmeras possibilidades de aprender.

Houve também a promoção de encontros em horários diferenciados, para que não houvesse a necessidade de dispensa das aulas e para que todos os conselheiros que trabalham em horário comercial pudessem participar para estudar as legislações que regem os encontros escolares através de estudos dos cadernos sobre Conselhos Escolares e do Estatuto do Conselho Escolar Municipal.

Um dos encontros com os membros do Conselho Escolar foi para se conhecerem as atribuições e finalidades do conselho e que constam do Estatuto do Conselho Escolar, definindo-se, assim, as obrigações para transformar a escola em Centro de Integração e Desenvolvimento Comunitário, aprimorando-a como agente de seu próprio desenvolvimento em estreita colaboração com os órgãos do poder público e outras entidades.

Houve, com essas ações, uma maior aproximação e cooperação entre pais, alunos e professores, de modo a sensibilizar os membros da comunidade para as atividades comunitárias, gerando uma motivação para a programação e o funcionamento de cursos comunitários - atividades culturais, palestras, reuniões, seminários, grupos de estudo, exposições, projeções de filmes, campanhas. O Conselho Escolar, assim, contribuirá para a solução dos problemas, possibilitando a convivência harmônica entre pais ou responsáveis legais, professores e alunos.

Promoveu-se, também, a confecção de cartazes sobre o Conselho Escolar para serem trabalhados na escola com alunos, funcionários e professores, com o objetivo de mostrar a importância das funções do Conselho Escolar. Este terá encontros periódicos para se discutirem as prioridades da escola, com a finalidade de se criarem formas de colaboração comunitária, considerando-se as condições financeiras de cada família. Essa integração da escola com a comunidade visa à interação e à participação no desenvolvimento do projeto pedagógico, estimulando e orientando a formação de comissões para a realização de tarefas específicas, de acordo com as necessidades da escola e da comunidade, e ainda conscientizando a comunidade, pelos meios de comunicação, no sentido de valorizar as ações educativas. 


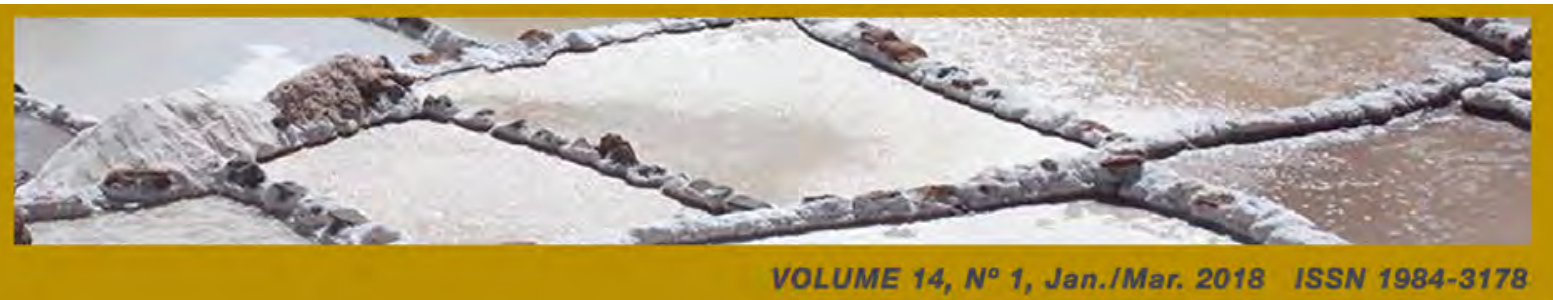

Para que isso tudo ocorresse, o Conselho Escolar ficou incumbido da elaboração de relatórios sobre as atividades desenvolvidas na escola para que toda a comunidade escolar tenha acesso. Nesses relatórios, haverá uma avaliação contínua dos membros do Conselho sobre as necessidades e o desempenho do próprio Conselho, para que seja revisto o que for preciso para o bom andamento da comunidade escolar.

Com o intuito de promover a integração do Conselho Escolar ao Projeto PolíticoPedagógico (PPP), organizou-se uma reunião extraordinária com toda a equipe pedagógica, com os membros da antiga APP (Associação de Pais e Professores) e com o Conselho Deliberativo, para a reelaboração do PPP (Projeto Político-Pedagógico). Na mesma reunião foi estudado o Estatuto do novo Conselho Escolar.

Com a formação do Conselho Escolar, pretende-se que a comunidade participe ativamente das decisões e das responsabilidades sobre o ensino. Essa é uma proposta nova em nosso município, organizada em 2010, visto que anteriormente exerciam parte desses papéis as Associações dos Pais e Professores (APP).

Diante da criação do Conselho Escolar, espera-se que a participação de todos não seja apenas para assinar papéis, mas para promover discussões e encontrar soluções relativas às problemáticas da escola, e que nasça o sentimento de pertença no grupo e haja fiscalização.

\subsection{DIFERENCIANDO ASSOCIAÇÃO DE PAIS E PROFESSORES DE CONSELHO ESCOLAR}

A APP é constituída pelos pais ou responsáveis legais por alunos, corpo docente e pessoas da comunidade que tiverem sua admissão aprovada pela diretoria por terem prestado serviços relevantes à unidade escolar.

A Associação tem por finalidade específica promover a integração EscolaComunidade, em termos da conjunção de esforços, articulação de objetivos e harmonia de procedimentos. O que a caracteriza principalmente por estimular a transformação da Unidade Escolar em Centro de Integração e Desenvolvimento Comunitário, aprimorando-a como agente de seu próprio desenvolvimento, promovendo a aproximação e a cooperação dos 
membros da comunidade para as atividades escolares e dos associados da APP para as atividades comunitárias.

A Associação de Pais e Professores (APP) é uma entidade de decisão coletiva, tendo por finalidade conjugar os esforços entre escola e comunidade, para estimular a transformação da escola em centro de integração e desenvolvimento comunitário, por meio da participação da família na escola, e da escola na comunidade (ESTATUTO da APP, Escola Centro Educacional Municipal São Cristóvão de 2007).

Por determinação da Secretaria Municipal da Educação, o Centro de Educação Municipal São Cristóvão formou em 28 de outubro de 2009 o Conselho Escolar da Educação, em substituição à Associação de Pais e Professores. Na ocasião, foi realizada uma reunião para a entrega de livros e cartilhas sobre o Conselho Escolar, bem como do Estatuto pertinente à referida escola. Tal atitude abrangeu todas as escolas da rede municipal de Fraiburgo.

Com a criação dos conselhos, há a pretensão de obtermos uma educação democrática e de qualidade, em que a cultura e o pensamento de todos sejam respeitados. Uma gestão democrática e participativa deve contar com a colaboração de todos, desde alunos, corpo docente, pais e membros da comunidade.

A escola pública contribui significativamente para a democratização da sociedade para o exercício da democracia participativa, formando cidadãos conscientes e comprometidos com os interesses da maioria da comunidade escolar. Nesse sentido, a formação e organização dos dirigentes dos conselhos escolares e de toda a comunidade escolar para participar e fazer valer os seus direitos e deveres, democraticamente discutidos e definidos, é um exercício de democracia, humanidade e justiça social (BRASIL, 1996).

A formação do Conselho Escolar na Escola Centro Educacional Municipal São Cristóvão contribuiu para uma gestão democrática e transparente, porém encontramos dificuldade para formar o Conselho Escolar, devido à participação espontânea da comunidade, especialmente dos pais. Diante disso, se tornou necessário buscar esclarecimentos sobre as 


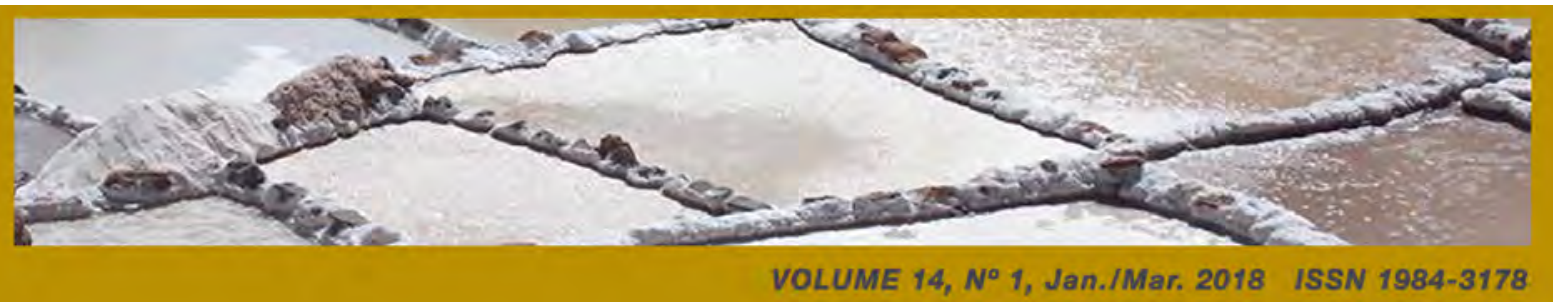

questões levantadas, para que o Conselho Escolar fosse efetivado de maneira eficaz e democrática. Assim, buscou-se na literatura a importância das APPs nas escolas. Segundo Oliveira, Moraes e Dourado,

A Associação de Pais e Mestres, enquanto instância de participação constitui-se em mais um dos mecanismos de participação da comunidade na escola, tornando-se uma valiosa forma de aproximação entre os pais e a instituição, contribuindo para que a educação escolarizada ultrapasse os muros da escola e a democratização da gestão seja uma conquista possível (2010, p. 12).

A APP escolar possui, dessa forma, importante função perante a comunidade local e escolar; o Conselho de Escolar, no entanto, é um órgão que incorpora a funções da antiga APP na gestão e no processo de ensino e aprendizagem desenvolvido na referida unidade escolar, não sendo necessária a sua extinção.

O Conselho Escolar constitui-se numa das instâncias de vital importância em um processo de gestão democrática, sendo que: "Guarda em si a possibilidade de articular os diversos segmentos da escola e tem por objeto de estudo o processo de ensino, que é o eixo central em torno do qual se desenvolve o processo de trabalho escolar" (DALBEN, 1995 apud OLIVEIRA; MORAES; DOURADO, 2010, p. 12).

Com a criação do Conselho Escolar, há a pretensão de obtermos uma educação democrática e de qualidade, na qual a cultura e o pensamento de todos sejam respeitados. Uma gestão que tem características democráticas e participativas deve contar com a colaboração de todos, desde alunos, corpo docente, pais e membros da comunidade. O Conselho Escolar, por conseguinte, tem a finalidade de assegurar a participação de todos os segmentos da comunidade escolar na gestão democrática, com funções de caráter fiscalizador, consultivo, normativo, deliberativo e avaliativo, visando promover o fortalecimento da autonomia pedagógica, administrativa e financeira da Unidade Escolar. Os representantes devem atender às demandas da comunidade escolar para a construção de uma sociedade mais justa. 


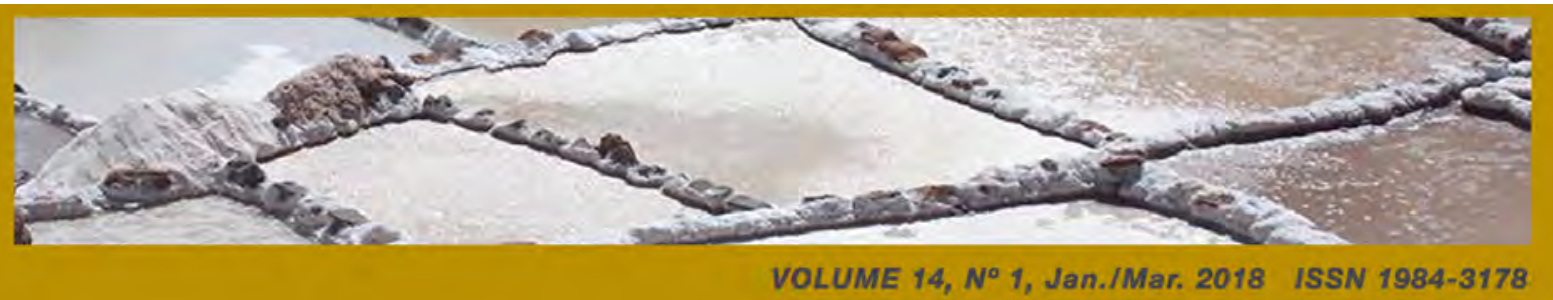

Entendemos, assim, que o trabalho do Conselho Escolar acontece na mesma medida em que seus componentes se engajarem e houver condições mais favoráveis ao crescimento do aluno e do professor como seres humanos, agentes de sua realidade.

\section{CONSIDERAÇÕES FINAIS}

No exercício de democracia participativa, o estudo e o fortalecimento dos conselhos escolares têm sido um desafio aos gestores. Com o desenvolvimento do Projeto de Intervenção, vários itens foram esclarecidos e nortearão futuras práticas. O debate possibilitou a construção do conhecimento sobre o assunto, buscando-se constantemente alternativas viáveis para que haja realmente a participação de todos.

Entendemos que o trabalho pedagógico acontece na proporção em que se vive num meio sobre o qual é possível agir, discutir, decidir, realizar, avaliar, engajar-se e responsabilizar-se pelo processo de ensino e aprendizagem, onde são criadas as condições mais favoráveis ao crescimento do aluno e do professor como cidadãos, agentes de sua realidade.

A criação dos Conselhos Escolares vem ao encontro das necessidades da gestão participativa, substituindo concepções que abrangiam apenas as questões burocráticas da instituição. O objetivo da formação dos conselhos escolares é muito importante se eles forem realmente alcançados, deixando de ser utópicos. Se, com a formação dos mesmos, queremos novas ações, também há necessidade de mudança da estrutura pedagógica e burocrática, possibilitando que os membros se apropriem do conhecimento que o conduza à participação efetiva na comunidade escolar.

Desse modo, a educação é um processo que integra o conhecimento científico e o empírico, a escola e a vida, preparando o jovem para interagir no seu contexto social com ética, consciente de seus valores, direitos e deveres como cidadão do mundo.

Interessante também ressaltar que após sete anos de implantação do Conselho Escolar (2010 - 2017), muitas mudanças já aconteceram, dentre elas especificamente cabem destacar o aumento significativo da participação nas tomadas de decisão do Centro Educacional 
referentes as organizações de festas, investimentos estruturais e sobretudo, na atuação dos pais no Centro.

Sendo assim, mais do que um Órgão Participativo o Conselho Escolar de fato propicia a atuação da Gestão Escolar Democrática, elemento indispensável para a Gestão de sucesso nas Instituições atuais.

\section{REFERÊNCIAS}

AZEVEDO, J. M. L. de. O projeto político-pedagógico no contexto da gestão escolar. 2010. Disponível em: <http://moodle3.mec.gov.br/ufsc/>. Acesso em: 9 ago.2010.

BRASIL. Leis de Diretrizes e Bases da Educação Nacional - LDB. Lei nº 9.394, de 20 de dezembro de 1996. D.O.U., de 23 de dezembro de 1996.

- Ministério da Educação e Cultura. Secretaria da Educação Básica. Conselhos Escolares: uma estratégia de gestão democrática da escola pública. Brasília: 2004.

Ministério da Educação. Secretaria de Educação Básica. Programa Nacional de Fortalecimento dos Conselhos Escolares: democratização da escola e construção da cidadania. Brasília: 2004.

. Recorte da lei do Sistema Estadual de Educação - Art. 18 a 21 - SEE/SC, Lei Complementar $\mathrm{n}^{\mathrm{o}} 170 / 1998$.

BUZO, L.; MACHADO, H. P. V. Gestão democrática escolar e a participação do conselho escolar: uma reflexão. Disponível em: <http://moodle3.mec.gov.br/ ufsc/file.php/6/Conselhos_Escolares/pdf>. Acesso em: 12 ago. 2010.

CASTRO, M. L. S. de; WERLE, F. O. C. Projeto político-pedagógico como instrumento de autonomia nas redes municipais de ensino público. Perspectiva, Florianópolis, v. 23, n. 01, p. 191-221, jan./jul. 2005. Disponível em: $<$ http://www.perspectiva.ufsc.br/nucleos/nup/perspectiva.html $>$. Acesso em: 16 ago. 2010.

CURY, Carlos Roberto Jamil. O direito à educação: um campo de atuação do gestor educacional na escola. Disponível em: $<$ http://moodle3.mec.gov.br/ufsc/ $>$. Acesso em: 9 jul. 2010 .

FARFUS, Daniel. Gestão escolar: teoria e prática na sociedade globalizada. Curitiba: Ibpex, 2008. 


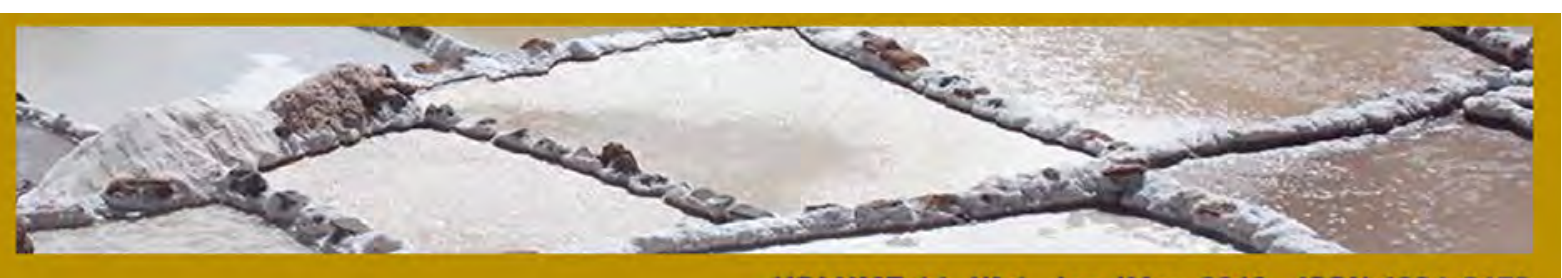

LIBÂNEO, J.C. Organização e gestão da escola: teoria e prática. 5. ed. Goiânia: Alternativa, 2004.

NAVARRO, I. P. Ministério da Educação. Secretaria de Educação Básica. Programa Nacional de Fortalecimento dos conselhos escolares. vol. 5. p. 49-51. 2004. Disponível em: $<$ http://moodle3.mec.gov.br/ufsc/>. Acesso em: 15 ago. 2010.

OLIVEIRA, J. F. de; MORAES, K. N. de; DOURADO, L. F. Gestão escolar democrática: definições, princípios, mecanismos de sua implementação. Disponível em: $<$ http://moodle3.mec.gov.br/ufsc/>. Acesso em: 9 ago.2010.

PARO V. H. Administração escolar: introdução crítica. 14 ed. São Paulo: Cortez, 2006.

SANTA CATARINA. Decreto $\mathrm{n}^{\circ} 3.429$, de 08 de dezembro de 1998. Regulamenta o Conselho Deliberativo Escolar nos estabelecimentos de ensino de educação básica da rede pública estadual.

. Portaria N/008/99 de 27/05/99 - (publicada no DO-SC N. 16.177, de 01.06.1999). Regulamenta os procedimentos referentes ao Conselho Deliberativo Escolar nas Unidades Escolares de Educação Básica da Rede Pública Estadual.

SILVA, I. M. da. Autoavaliação e gestão democrática na instituição escolar. Ensaio: Avaliação e Políticas Públicas em Educação. v.18, n. 66, Rio de Janeiro Jan./Mar. 2010.Disponível em: $<$ http://www.scielo.br/scielo.php?script=sci_ arttext\&pid=S0104-40362010000100004\&lang=pt $>$ Acesso em: 15 ago. 2010.

SOUZA, A. R. de et al. Centro Interdisciplinar de Formação Continuada de Professores; Ministério da Educação, Secretaria de Educação Básica. Curitiba: Ed. da UFPR. Caderno 1 da Coleção Gestão e avaliação da escola pública, p.15-22. 68 p, 2005. Disponível em: $<$ http://moodle3.mec.gov.br/ufsc/mod/data/view.php?d=

101\&advanced $=0 \&$ paging $=\&$ page $=1>$. Acesso em: 15 ago. 2010.

SOUZA, A.R. de. Explorando e construindo um conceito de gestão escolar democrática. Educação em Revista, v. 25, n. 3, Belo Horizonte, Dez. 2009. Disponívelem: $<\mathrm{http}: / \mathrm{www}$. scielo.br/scielo.php?script=sci_arttext\&pid= S010246982 009 00300007\&lang=pt $>$. Acesso em: 15 ago. 2010.

VEIGA, I. P. A. Inovações e projeto político-pedagógico: uma relação regulatória ou emancipatória? Cad. CEDES, Campinas, v. 23, n. 61, Dec. 2003. Disponível em: $<$ http://www.scielo.br/scielo.php?script=sci_ arttext\&pid=S0101-326220 $0300 \quad 61 \quad 00$ 002\&lng=en\&nrm=iso $>$. Acesso em: 18 ago. 2010. 